\title{
Editorial
}

\section{Incorporando evolução}

Conforme anunciado, a partir deste número, tem início a estrutura de dossiês temáticos, sendo o primeiro denominado Imagem e Política. $\mathrm{O}$ ano que se encerra foi marcado pela atividade política conferindo novos sentidos à consciência cidadã, tanto por uma convulsionada campanha eleitoral, como pela cotidiana cobertura midiática de escândalos, cujos protagonistas detêm poderes de decisão capazes de afetar os indicadores socioeconômicos e, consequentemente, a vida da população. Foi também um período de manifestações em que se vem notando uma ampliação da capacidade de reação e de expressão, proveniente dos mais variados setores. Por um contexto desse tipo, tão próximo no tempo, era um tema mais do que oportuno, e os organizadores desta edição se mostram contentes pela resposta dos pesquisadores e os agradecem por terem escolhido publicar nesta revista.

Um dos estudos aqui veiculados apontou padrões convergentes no uso das videografias do YouTube e o papel desse fator nos desdobramentos que influenciaram o que ocorreu nas demonstrações de rua nos casos "Fora Feliciano" e "Fora Renan". Estudando as postagens e suas características, o artigo mostra como vídeos curtos e narrativas enfatizam os registros de protestos e a manifestação de opinião. Na mesma linha, o texto intitulado Brasil, entre as telas e as ruas discute os desafios que as mediações culturais e tecnológicas impuseram ao jornalismo audiovisual na cobertura dos protestos de Junho de 2013. Ao se inserir em outras telas que não as da TV, o público tem acesso a, e faz uso de, formas inovadoras de intervir na história contemporânea, colocando em crise a tradicional relação entre produção e recepção massiva.

À luz da reflexão de Jacques Rancière, em outro artigo, é debatido o modo como uma "política da imagem" se revela na produção criativa do dissenso nas cenas em que o político emerge, aparece e se constitui por meio de um processo de subjetivação. Divergência, desavença, discrepância e contraste desconectam significações e visibilidades, e conectam-se a gestos de sobrevivência: operações e agenciamentos para resistir a capturas e excessos dos discursos construídos, midiaticamente, pelas instituições sociais e pelo Estado. 
As subjetividades estão também presentes em outro artigo, que analisa imagens em três categorias de filmes que contemplam regimes políticos ditatoriais: documentários, filmes baseados em fatos reais e filmes ficcionais. O ponto principal é que documentar a "factualidade" pode contribuir para a "memória-metamorfose", e é com ela que se promove diversificação nas representações das ditaduras em filmes. As bases conceituais são extraídas de Bakhtin, Baudrillard, Benjamin, Debord, Derrida, Halbwachs, Metz, Nichols e Sarlo, entre outros.

A incorporação do formato dossiê é bastante presente em outras publicações, e essa prática abre campo para um recorte e direcionamento, com mais especificidade, no tratamento de um objeto de pesquisa e de um campo teórico. Neste sentido, o que se deseja oferecer, à comunidade científica dedicada aos estudos da imagem, é um campo aberto à disseminação e ao teste das proposições e da reflexão a que o pesquisador deu andamento. Não está suprimida, no entanto, a publicação de artigos com temáticas diferentes das anunciadas no dossiê. É reservada igual extensão para essa finalidade, como se pode observar neste número: estão também presentes artigos com temas abrangendo fotografia de ficção, fotografia e memória, imagem na sua ligação com o cinema e a literatura. Cabe salientar que, embora em sua designação, este periódico contenha a expressão fotográficos, é nos estudos da imagem e das visualidades (e seus impactos cada vez maiores na sociedade de hoje) que deve ser inspirada a proposta investigativa.

As alterações empreendidas na revista estão gerando frutos. Elas são principalmente de natureza organizacional, de modo a assegurar maior amplitude e envolvimento da equipe de pesquisadores. A alternância entre os editores (cada dossiê temático está a cargo de uma dupla diferente) é salutar porque permite um melhor aproveitamento da experiência desses coordenadores e do conhecimento que possuem no assunto do dossiê. É cada vez mais reconhecido que a atividade de pesquisa requer trabalho coletivo, e é unicamente na interação que a produção científica se robustece, diversifica, ganha credibilidade. A revista Discursos Fotográficos conquistou um prestígio que é oriundo de sua personalidade e dela não abre mão - o que acaba de fazer é impor, a si própria, novas metas: a principal e inalterável é a busca da excelência.

Tenha uma boa leitura!

Flora Neves

Miguel Contani 